\title{
7. Demythologising Flynn, with Love: contesting missionaries in Central Australia in the twentieth century
}

\author{
DAVID TRUDINGER
}

Central Australia was (and is) both a mythical and a contested landscape. The historical contest there was not always confined to whites and Indigenous people, or to land-hungry settlers and distant administrators. Nor were its myths only ancient, indigenous ones. One of the better known Australian 'myths' is that of John Flynn (1880-1951), the founder of the Australian Inland Mission (AIM) and the man who through the innovative Royal Flying Doctor Service (RFDS) brought medical assistance to people isolated in the Australian outback. The canonisation of Flynn commenced in 1932 with Ion Idriess's book, Flynn of the Inland, which represented him as a paragon of all the virtues, as a saint of the Inland. ${ }^{1}$ Even Flynn saw the book with some irony as creating 'my mythical self'. ${ }^{2}$ This construction of Flynn as a kind of universal, ministering spirit of the Outback has been developed subsequently in newspapers, books, films and television, reaching its apotheosis with Flynn's portrait on the 20-dollar note. Fulsome encomiums continue to be presented to a humanitarian 'on the highest level' and, along with Parkes, Monash and Bullwinkle, 'one of the founders of the national spirit of Australia'. ${ }^{3}$

However, the reorientation of Australian historiography in relation to Indigenous people in the last two or three decades has forced some preliminary scrutiny of the Flynn myth, particularly in relation to his attitudes towards Aboriginal people. ${ }^{4}$ This essay enters this contested territory, by looking afresh at Flynn in the context of internal debates between Presbyterian missionaries in the 1930s and 1940s. The key players in these debates, apart from Flynn himself, were Dr Charles Duguid (1884-1986), the sponsor of Ernabella, a significant twentieth century missionary venture to Aboriginal people in the Centre, and missionary,

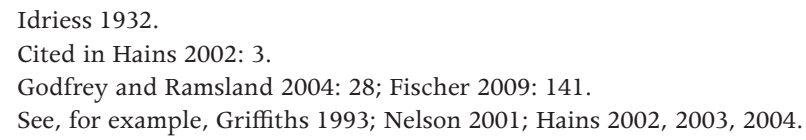


linguist and teacher, JRB Love (1889-1947). I suggest that Flynn's long career, famously and single-mindedly dedicated to throwing a 'mantle of safety' over the Inland through the provision of communication and medical services, may also have been notable for a culpable indifference towards Indigenous people and an exclusion of them from his vision for the Inland. I also argue that Flynn's attitudes towards Aborigines, and those of the AIM, were strenuously contested by important denominational colleagues at the time.

Memory, as well as myth, plays a part in this story. Some of the memories are mine. I remember the opening of the John Flynn Memorial Church in Alice Springs in 1956; I am six and I am there with my missionary mother and father. ${ }^{5}$ The Governor-General, Sir William Slim, dedicated the Church. I am unaware of Slim's earlier pronouncement that Flynn's hands were stretched out like a benediction over the Inland but I do have an inchoate sense that Flynn, only five years dead, is already being constructed as a sort of 'national saint'. ${ }^{6}$ About this time I am also being educated through the School of the Air, courtesy, I am told by my parents, of Flynn and Alfred Traeger. ${ }^{7}$ I am impressed, and remain so, with reservations. Flynn's stewardship, through the medium of the AIM, of the white settlers of the Inland was superb, and has ever since been generously acknowledged by a grateful (white) nation.

On the other hand, the 'stewardship' of Indigenous people was a task that Flynn left to others. Justifications for this omission, where it has been recognised, have been varied. The principal 'defence' used by the AIM itself was that other arms of the Presbyterian Church, its Board of Missions and missions for Aborigines, dealt with Aborigines, not the AIM. Another rationale was that Flynn could not have achieved what he did without a single-minded devotion to the cause of the white settler. ${ }^{8}$ An explanation sometimes attached to this argument but often merely implied was that any accommodation with the 'blacks' would have resulted in the disaffection of the whites and the consequent loss of effectiveness of the AIM. ${ }^{9}$ The respected Lutheran missionary FW Albrecht of Hermannsburg believed that the medical assistance given to Aborigines, admittedly as out(side) patients at AIM hospitals and through the RFDS, was ultimately more beneficial for Aborigines than almost anything else done for them by Europeans. ${ }^{10} \mathrm{Dr}$

5 My parents were missionaries at Ernabella.

6 See Hains 2002: 168.

7 Traeger worked with and for Flynn in developing a communication network for the Royal Flying Doctor Service (RFDS) and the School of the Air, and famously invented the pedal wireless: see Behr 1990.

8 A 'defence' used often by some experienced Centralian hands: Winifred Hilliard, a long-term missionary at Ernabella and author of the pioneering The People in Between (see Hilliard 1976), argued this in recent discussions with the present author.

9 JRB Love understood this justification instinctively, with his experience in the Outback, although he thought the AIM should have stood up against the 'bush' discourse (see below).

10 Albrecht in later years wrote to Duguid: 'If Flynn had intended the Aerial Medical Service in the first place for white settlers, God had had His plans for the Aborigines, so that in real fact very many more Aborigines than white people, old and young, benefited from this service': Albrecht to Duguid, 28 March 
George Simpson of the AIM in an exchange of letters with Charles Duguid in 1935 also argued perceptively that by casting his 'mantle of safety' over the Inland, Flynn made it possible for white women to migrate there and thus 'ease the pressure' on abused Aboriginal women. ${ }^{11}$ Later commentators suggested, more broadly, that Flynn prepared the Outback for 'the new age for the Aboriginal people'. ${ }^{12}$

These are, in the main, substantive defences of varying degrees of merit, which in a larger work would need to be taken into account in a balanced consideration of Flynn's significant contribution to his country. Taken together they suggest that at least the indirect influence of Flynn's work on the Indigenous population of the Outback may well have had some positive elements. But hitherto, the case against Flynn, if there is one, has essentially relied on sins of omission. I am suggesting here that at least a provisional argument exists for sins of commission on Flynn's part as well, some thinking and behaviour actually antithetical to Indigenous interests. To unravel that story, we need first to look at the relationships between our protagonists, Flynn, Duguid and Love, whose paths, like tracks in the desert, crossed, separated, aligned or collided over the first half of the twentieth century in Central Australia.

\section{JRB Love and John Flynn}

In 1912, the Presbyterian Church of Australia commissioned John Flynn to conduct a survey of 'religious conditions' in the Northern Territory. According to Flynn's first biographer, his preparations for the journey related both to the subjects of 'aborigines as well as whites': '[Flynn] had many discussions with his friend Robert Love, a young schoolteacher at Leigh Creek.'13 Indigenous people, however, did not figure prominently in Flynn's Report or his plans for an Australian Inland Mission (AIM), which was to be a mission to the white settlers of the Inland. The Presbyterian Church speedily approved and established the AIM within the year. Later in 1912, Love set out from Leigh Creek in South Australia to report on 'the present condition' of the Aborigines 'in the North' for the same Presbyterian Church. Perhaps he had divined that Aborigines were not part of Flynn's vision. Perhaps they had agreed on some sort of division of labour. We do not know. In his Report, Love recommended that the Church establish missions 'to the blacks' in this large area, but this advice was not carried out. By the time his report was received in December 1914, and published in 1915, the Great War was under way. The question of establishing new missions to the Aborigines, if it had been seriously considered

1971, Papers of FW Albrecht, Burns-Albrecht Collection, South Australian Museum Archives, AA662.

11 See Trudinger 2004: 122-123.

12 For example, see Griffiths 1993: 168.

13 McPheat 1963: 60. 
at all, was deferred indefinitely. The Church instead proceeded to fall in behind the powerful and popular force the AIM was becoming, with Flynn at its head. For his part, however, Love had been ready. As he wrote to Flynn in 1914:

shall the Church be prepared to act at once [on his Report], and make a proposition to me as a layman, I shall at least seriously consider it. Failing either of these alternatives, my intention is to come back to bushwhacking till I fall off a horse or bump into a spear. I could go back to a respectable sort of life in the South with the approval of my friends, but for myself I do not think I shall ever do so. ${ }^{14}$

In fact Love's Church was not 'prepared to act' in establishing a mission for Aborigines anywhere in Australia for another 23 years, until Duguid's Ernabella in 1937.

After their 'reporting on the North', the careers of Love and Flynn took divergent courses. By the end of the 1920s, Love had been to war in Palestine, won the Military Cross and the Distinguished Conduct Medal, acquired a divinity degree and ordination, and had been working as a Presbyterian missionary to Aborigines, in Mapoon, Queensland and in Western Australia, at Kunmunya in the Kimberley. John Flynn was continuing to construct the increasingly influential AIM and fashioning his 'mantle of safety' over the Inland. ${ }^{15}$ Love and Flynn continued to correspond occasionally, keeping in touch, with intermittent discussions about Aboriginal matters. They both appear to be in the mainstream of contemporary racial discourse in Australia that saw European civilisation as the apogee of societal development, and Europeans as certainly superior to 'native' races. Both believed as did significant members of the scientific and intellectual communities in the creation, despite some residual anxieties, of a preeminent white Australian race or type. ${ }^{16}$ Yet there were differences between them.

\section{JRB Love}

Love's attitudes towards Aboriginal people were often ambivalent. The discourses of European conquest, development and racial triumphalism both clash and merge in Love's thought with those of reparation, responsibility, and redemption. In his 1914 Report, the young schoolteacher had stridently

14 Love to Flynn, 9 February 1914, John Flynn Papers, National Library of Australia [hereafter NLA], MS3288, Box 3, Folder 2.

15 This familiar story is told in McPheat 1963; Griffiths 1993; Rudolph 2000. I do not want to give the impression through brevity that the 'rise' of the AIM was inevitable or easy, or to under-estimate Flynn's achievement. That his organisation was becoming a significant and important actor, as he himself was, is I think indisputable.

16 Anderson 2002 
advised the Church that 'it would be foolish to argue that all men are equal. The blackfellow is inferior and must necessarily remain so' ${ }^{17}$ Despite this inequality, he had told Flynn earlier that the destinies of the two 'races' were inextricably entwined: 'The question of white and black are wholly bound up in each other. We cannot deal with one apart from the other. ${ }^{\prime 18}$ This view was partly generated by Love's concerns about sexual relationships between white and black in the Inland. He commented to Flynn on the consequences of these unions in language that is objectionable to us now but was relatively standard usage at the time: 'The half-caste is a nigger, and can only (but for some exceptions) marry a black or a half-caste. The quadroon is a white, and should be brought up as such. ${ }^{19}$ With his distaste for hybridity, shared by Flynn, complicating his arguments for a unity of approach, Love did not convince the older man, whose long career appears to have been characterised by a determination, soon after the commencement of his work with the AIM, to deal only with the one and not with the other.

On one seminal matter, the dispossession of the Indigenous peoples of Australia and its consequences, Love's views were unusual for his time. In 1922, while at Mapoon, he published a small 36-page booklet called Our Australian Blacks in which he proposed a paternalistic but powerful theory of colonial duty towards Aborigines. ${ }^{20}$ The duty arose 'because we are living on their land ... we have taken it from the people who first owned it, without paying for it'. Love argued that the dispossession was justified: '[we] had the right to take the land, which was not being developed, and to put it to better use', which did reflect thinking among many white colonial Australians. ${ }^{21}$ He was careful, however, to explain that 'the Blacks did not cultivate the soil [because] there is no native plant in Australia that can be cultivated to produce large food crops ... so the blackfellow had no chance to develop the country' ${ }^{22}$ Love's acknowledgement of the environmental deficits that Aborigines had been faced by Aborigines on this continent was one that was not commonly made. He went on to present a further and crucial corollary to the justified dispossession: the right to dispossess creates an obligation to care for the dispossessed, as a gesture of recompense and reparation. This duty became, for Love, paramount: 'no honest or Christian person would say that we have a right to live in a land without taking proper care of the aborigines'.$^{23}$

17 Love 1915: 29.

18 Love to Flynn, 9 February 1914, John Flynn Papers, NLA, MS3288, Box 3, Folder 2.

19 Love to Flynn, 9 February 1914, John Flynn Papers, NLA, MS3288, Box 3, Folder 2.

20 Love 1922. Despite the fact that this booklet's audience is children, or perhaps because of it, Love's

exposition of a complex colonial duty is succinct and lucid.

21 Love 1922: 35.

22 Love 1922: 8.

23 Love 1922: 35. 
In 1926, Love was dryly deprecatory to Flynn about his own work at Mapoon: 'the ordinary routine work about smothers one and there is little time to raise one's head and look around. I suppose the case of some 350 niggers and half-castes is a fairly useful job, though a good deal different from earlier visions. ${ }^{24}$ In the same year, Love accepted an appointment as superintendent of Kunmunya Mission in Western Australia where he was to remain for 14 years. By the late 1930s, he had built a large reputation within church circles as a linguist, anthropologist, and scholar. ${ }^{25}$ He has been described by the Presbyterian historian Robert Scrimgeour as 'one of the greatest sons' of the South Australian Church, a 'friend of the Aborigines', and by John Harris in his magisterial survey of the Aboriginal encounter with Christianity as an exemplary and progressive missionary. ${ }^{26}$ Yet Love could still write in 1936, after 15 years of missionary enterprise, that a mistake of the 'young enthusiast' might be to treat 'the Aborigine as an equal, which can only lead to friction and heartbreak' ${ }^{27}$ Earlier, in 1930, he had cited his pride in the Lamarckian 'type' that had evolved in the Antipodes, the 'white Australian', but had emphasised also the need for 'honour' in national conduct towards the Aborigines. ${ }^{28}$ Love grasped the fundamental and moral nature of the obligations conferred on Europeans by the original sin of dispossession. For a man enmeshed as he was in the discourses of empire, of race and white civilisation, JRB Love was making an effort, as he had put it, 'to deal honourably and wisely with the Aboriginal' ${ }^{29}$ But was John Flynn doing so?

\section{Charles Duguid and John Flynn}

In the first issue of the AIM newspaper, the Inlander, in 1913, Flynn acknowledged that 'the condition of these blacks is not what one would like to see, but one must not fly to hasty conclusions about causes and remedies'.${ }^{30}$ White residents of the Inland were generally kind, pitying and generous towards Indigenous people,

24 Love to Flynn, 25 April 1926, John Flynn Papers, NLA, MS3288, Box 4, Folder 7.

25 Love had translated part of the Bible into the Worora language of the Kimberley area, completed a MA in linguistics at Adelaide University, corresponded with AP Elkin and written for Oceania about matters anthropological, and had produced a book which outlined, for its time, a new and progressive missiology: see Love 1936. Love's missiology emphasised the grafting of Christianity onto Indigenous culture and spirituality in contrast to the orthodox exclusivist view that Christianity had to replace Indigenous pagan beliefs. To later historians such as John Harris, Peter Biskup, and Richard Broome, JRB Love was an exemplary progressive missionary, practicing a moderate, tolerant and patient policy of 'enlightened gradualism' (Biskup), an example of a 'liberal humanitarian missionary' (Broome): see Harris 1990: 543-544; Biskup 1973: 127; Broome 1994: 109-110.

26 Scrimgeour 1986: 215-216; Harris 1990: 543-544, 836-838.

27 Minutes of Proceedings of the General Assembly of the Presbyterian Church of Australia 1936, Presbyterian Church of Australia [hereafter PCA]: 96. Love is cited, however, in the same year (1936) as writing: 'I yield to none in recognizing the real intellectual ability of the Australian Aborigines' (cited in McKenzie 1969: 245). This statement and the one in the text, while not necessarily contradictory, give some indication of Love's ambivalence regarding Aborigines.

28 Love, cited in McKenzie 1969: 260.

29 Love, cited in McKenzie 1969: 260.

30 Flynn 1913: 10. 
according to Flynn's optimistic view, but he conceded that these attitudes were ones 'in which domestic animals share'. Whites were struggling to survive, or prosper, themselves and could do little to help. While the Church needed to do 'something for the blacks, especially for the half-castes', said Flynn, 'we cannot enter into this difficult problem now'. ${ }^{31}$ This statement is a succinct representation of Flynn's attitude to Aborigines, an apparent synecdoche of a broader abandonment. While John Flynn did make some sympathetic statements about Aborigines in the first years of the AIM's existence, particularly in the first few issues of the Inlander, these 'sympathetic noises' appear to trail away into an awkward and revealing silence as his public career blossomed. ${ }^{32}$ By 1937, he could write to an AIM operative that 'I believe the idea is emerging that the AIM's job is to care for the souls of the dispersed whites and to assist to establish and maintain appropriate organizations to care for the bodies of whites and blacks alike and the nearest approach to souls which may be lingering in the dusky hides of the latter'.$^{33}$ Flynn's early sympathy seemed to be dissipating into something like indifference.

There was, and still is, a debate about the extent to which Aboriginal people were excluded from Flynn's imagining of the Australian community. ${ }^{34}$ Certainly, from about 1934 on, Dr Charles Duguid was convinced that Flynn's attitude, and that of his organisation, towards Aborigines was 'not human let alone Christian'. ${ }^{35}$ Duguid loomed large in the small universe of the South Australian Presbyterian Church of the early to middle twentieth century. Born in Scotland in 1884 and migrating to Australia in 1912, Duguid had become one of Adelaide's leading surgeons by the 1920s. His first visit to Central Australia took place in 1934 and led to a fierce commitment to the Aboriginal cause. ${ }^{36}$ Duguid was adamant that Flynn denigrated Aboriginal people. Central to Duguid's charge was the allegation that Flynn had warned him in 1934 that he was 'wasting his time among so many damned dirty niggers' ${ }^{37}$ In return, Flynn was said to have told the Secretary of the Board of Missions in 1936 that Duguid 'should have had his head chopped off years ago' ${ }^{38}$ Such were the polemics of Presbyterians.

\footnotetext{
31 Flynn 1913: 11.

32 An example of Flynn's early sympathy with the plight of the Aborigines: 'It should be quite unnecessary at this late day for us to point out that the black man as a member of the human race has a right to increasing opportunities of self-development ... surely we must ... do something for those whom we clean-handed people have dispossessed in the interests of superior culture': Flynn 1915: 27.

33 Flynn to Frank Pierce, 11 September 1937, Papers of John Flynn, NLA, MS 3288, Box 4, Folder 11.

34 See Hains 2002, 2003, 2004.

35 Duguid to Minister Perkins (copy), 2 October 1934, Duguid Papers, NLA, MS 5068, Series 1: general correspondence, 1918-1974 [hereafter Series 1].

36 See Duguid 1972: chapter 10.

37 Duguid 1972: 100. See also Tim Rowse's account of Duguid's first visit to Central Australia and his subsequent breach with the AIM and Flynn: Rowse 1998: 76.

38 Duguid to MacKenzie (copy), 11 February 1937, Duguid Papers, NLA, MS 5068, Series 1.
} 
It was not only the use of the term 'nigger' that was offensive to Duguid, although it is obvious that he disapproved of it. ${ }^{39}$ As we have seen, Love used it frequently as well. Flynn's major offence, to Duguid, was his implied indifference to and dismissal of Aborigines as a waste of time. Did Flynn say the offending words? Duguid was prone to hyperbole, and could be vituperative, but he was not, I think, a liar. Brigid Hains in her recent book on Flynn downplays Duguid's allegation as being 'nearly forty years after the event' ${ }^{40}$ But Duguid's charge was well known at the time within his Church. ${ }^{41}$ And there is little doubt that John Flynn at least privately spoke disparagingly of Aborigines. We have two impeccable witnesses to this 'fact': Howard Zelling, prominent lawyer and judge and elder in the Presbyterian Church of South Australia, and Pastor FW Albrecht. In the context of a furore in 1972 over the charge that John Flynn was a racist, Zelling wrote in the Advertiser: 'Whatever Flynn might have said on public platforms, he left no one in doubt in private conversations that his views were: (a) that the Aborigines were dying out and (b) they were lazy, shiftless good-for-nothings' ${ }^{42}$ Albrecht, the missionary at Hermannsburg, had observed in a letter to Duguid the previous year that 'I knew only too well that Flynn had little time for Aborigines; in our talks he often told me that their outlook in life personally and as future citizens was hopeless. ${ }^{23}$ But was there more to Flynn's thinking than indifference and an assumption of racial and cultural superiority?

\section{The Smith of Dunesk Gift}

When Charles Duguid was elected as the first lay Moderator of the South Australian Presbyterian Church in 1935, he immediately proposed a scheme to establish a mission among the Pitjantjatjara in the far north-west of the state. He charged his Church with a 'special moral responsibility' to the Aborigines of South Australia because of the misuse of a substantial 'gift' made in the nineteenth century by a Scottish woman, Mrs Henrietta Smith, of the estate of Dunesk. The gift had been donated for 'the aborigines of South Australia' but had been used instead to start John Flynn's AIM, a mission solely for the white pioneer population. An obligation, Duguid argued, now rested on the Church to divert the money, still being utilised by the AIM, back to its original purpose. ${ }^{44}$

39 Duguid to MacKenzie (copy), 11 February 1937, Duguid Papers, NLA, MS 5068, Series 1.

40 Hains 2002: 125-126.

41 He even relayed the story in a letter to the head of that church in 1939: Duguid to MacKenzie (copy), 25

February 1939, Duguid Papers, NLA, MS 5068, Series 1.

42 The Advertiser(South Australia), 6 September 1972: 5.

43 Albrecht to Duguid (copy), 28 March 1971, Papers of FW Albrecht, Burns-Albrecht Collection, South Australian Museum Archives, AA662.

44 Presbyterian Banner: the Organ of the Presbyterian Church in South Australia40(4): 10, in Papers of the Presbyterian Church of South Australia [hereafter PCSA Papers], Mortlock Collection [hereafter MC], State Library of South Australia [hereafter SLSA]. 
With resources scarce in the later 1930s, during the Depression and later in the context of war, the Smith of Dunesk funds now became a point of conflict for the local Church. In a sober assessment in 1986, historian Robert Scrimgeour commented: 'The Smith of Dunesk story is one that does not reflect credit on the Free Church of Scotland nor on the Presbyterian Church in South Australia. Throughout its history the bequest has been accompanied by frustration, discontent, and controversy.' ${ }^{\prime 5}$ I would add: intrigue, deception, and cupidity. It is a long and complex narrative which I have examined at length elsewhere. ${ }^{46}$ However, it is integral to the 'contest' involving Duguid, Love and Flynn, and a brief account of it weaves through the remainder of this text.

When Mrs Smith arranged for land to be purchased on her behalf in South Australia, she was dissuaded, almost certainly by someone associated with the Church in South Australia, from directing the proceeds 'to the evangelization and education of the Aborigines of South Australia', as she had wished. ${ }^{47}$ The deed of gift in 1853 only committed the annual rental income of the property to be applied 'to promoting the cause of the Gospel in South Australia'. But accompanying and later letters of Mrs Smith made it clear that her intention remained that her money, when possible, ought to be directed towards the Aborigines. ${ }^{48}$ However, the South Australian Church, after a period of quiet but lucrative accumulation, was determined in 1893 to put the money to 'other pious purposes', relying on the fact that the deed did not mention Aborigines while solemnly promising not to forget 'the interests of the aborigines' ${ }^{49}$ Their interests, having been largely ignored by the Church since 1853, were forgotten for another 40 years.

The Smith of Dunesk Mission, on the strength of the regular funding from Mrs Smith's properties, was established in 1895 in Beltana on the western fringe of the Flinders Ranges in South Australia, where a succession of padres, travelling by horse and buggy from station to station, operated a lonely ministry of worship (with a portable organ) and distribution of literature and good works to white settlers. A nursing sister was employed at Oodnadatta in the mission area from 1907. A travelling missionary and a nursing sister, bringing spiritual and physical health to the white Inland: this was a model that interested the Smith of Dunesk 'missioner' appointed in 1911, John Flynn..$^{50}$ In Beltana, before catching the train and boat to Darwin for his survey of the Territory, he built a medical

45 Scrimgeour 1986: 106 .

46 Trudinger 2004: chapters 4-6.

47 Scrimgeour 1986: 107-108. Six parcels of land of 80 acres each were purchased in 1851-1852.

48 At one point, Mrs Smith put her case in these terms: 'again I say not whites and no other colony has any right to a farthing of it': cited in Scrimgeour 1986: 108.

491893 Minutes, 8, Minutes of Proceedings of the South Australian State Assembly of the Presbyterian Church of Australia (hereafter Blue Books), PCSA Papers, MC, SLSA.

50 Flynn had previously become interested in 'the Bush' in Victoria, conducting two Shearers' Missions and producing a popular booklet The Bushman's Companion: see Flynn 1910. 
hostel, inaugurated a quarterly paper The Outback Battler, conducted services at Farina, Marree and at Leigh Creek where he met the young schoolteacher, Robert Love'. His vision, with his discourse, was already moving vigorously out from himself to take in panoramic vistas:

We are running well. Let nothing hinder us. The best and the brightest, the purest and most beauteous will ever be found clustered round the Cross of Christ. Let our devotion be complete in ourselves, and let us take no rest until our privileges and blessings are shared by all our nation, and by the child nation displaced by us, yet still within our gates. ${ }^{51}$

Flynn's language is revealing here. The inexorability of 'let nothing hinder us' is striking. 'Displaced' normalises and naturalises the original dispossession of the 'child race': children, also, move aside for adults, a natural social gesture. And while they too should share in our beneficence and 'privileges', the twist is in the phrase 'within our gates', which carries a connotation of 'the enemy within', some impurity within the 'pure and beauteous' body politic. As he laid his plans before his Church for a transformative project for the white people of the Inland, Flynn's ambivalence towards its Indigenous inhabitants is apparent.

\section{The Smith of Dunesk Gift and the AIM}

From 1912, the Smith of Dunesk Mission was progressively taken over by the AIM. Within 20 years, all the proceeds of the Smith of Dunesk fund were now to be devoted to the work of the AIM..52 By 1935, the AIM, which had been developed on the model of the Smith of Dunesk Mission, had swallowed up the parent organisation. The Smith of Dunesk Mission had been founded and funded on deception, misappropriation and a deliberate refusal to follow the express wishes of the benefactor for the benefit of the Aborigines of South Australia. Duguid was now inexorable in pursuing the re-appropriation of the money. The State Assembly of the Presbyterian Church conceded that at least part of the revenue from the Gift should be put to the use of the proposed mission, but failed in March 1936 to nominate how much. ${ }^{53}$ Better news for Duguid came in May when the Board of Missions decided to approve the formation of the mission Duguid was sponsoring, Ernabella, and to recommend it to the General

51 The Outback Battler, no 2 (1 July 1911), SRG 123/334, Smith of Dunesk Mission Committee. 7 Printed Items, PCSA Papers, MC, SLSA.

52 Presbyterian Church of SA, Blue Books, 1931, Report of Smith of Dunesk Committee, PCSA Papers, MC, SASL. See also Scrimgeour 1986: 115.

53 Presbyterian Church of SA, Blue Books, 1936, Report of the Smith of Dunesk Committee, PCSA Papers, MC, SASL. 
Assembly of the Church when it met in September later that year. ${ }^{54}$ Crucial support for Duguid's mission also came from Love, who from Kunmunya added his comments on the Smith of Dunesk matter:

I have been sore about this taking of blacks' money to help the whites, who were never in so dire need, ever since I was interested in the blacks; but my small voice went nowhere with effect. I am very glad that you have taken steps to right this wrong. Mind, the AIM is, I think, one of the greatest forces for good in our branch of the Church. ${ }^{55}$

Love's point as to the relative needs of the 'blacks and whites' of the Inland was one rarely made at that time. Love is I think also implying that the journey to the Centre by whites was generally voluntary, thus the moral case for priority in assistance was weakened.

The issue of the mission and the Smith monies remained divisive. Even the decision of the 1936 General Assembly of the Church to approve the Duguid Mission was distracted by controversy as Duguid now charged Flynn with obstruction: '[he] did everything in his power to stop the Mission I am sponsoring'. Duguid accused Flynn of posing as a friend to the native while working subtly to forestall the mission. ${ }^{56}$ How much truth was there to this allegation? There may have been some organised attempt at the 1936 General Assembly to obstruct the establishment of the Mission, by the use of delaying tactics. ${ }^{57}$ While the evidence is persuasive but not conclusive, it is interesting to note that Brigid Hains, generally supportive of Flynn, cites an unnamed Duguid supporter as describing Flynn as 'the devil incarnate' for his ability to argue for increased Aboriginal missions while at the same time undermining Duguid's work at Ernabella. ${ }^{58}$ Flynn's derogatory remark about Duguid cited earlier probably reflects an irritation with Duguid's attacks on the AIM as an organisation uncaring of Aboriginals, and similar comments about Flynn himself, which are littered about his writings, letters and, doubtless, his conversations, as well as Duguid's activism regarding Aborigines. His personal manner, abrasive and judgmental, was also not likely to endear him to Flynn.

54 Matthews to Duguid, 22 May 1936, Duguid Papers, NLA, MS 5068, Series 1.

55 Love to Duguid, 20 April 1936, Duguid Papers, NLA, MS 5068, Series 1.

56 Duguid to MacKenzie (copy), 11 February 1937, Duguid Papers, NLA, MS 5068, Series 1.

57 The Minutes of the 1936 Assembly show that after the motion to inaugurate Ernabella, an amendment was moved requiring the consent of the majority of the State Assemblies to the mission, which if successful would have resulted in at least delaying, if not defeating, the venture. According to Duguid, Flynn spoke in support of the amendment but 'a senior Presbyterian minister from Queensland' who said he was 'puzzled' by the opposition to the venture, and called on the withdrawal of the amendment apparently turned the tide. It was withdrawn: see Minutes of Proceedings of the General Assembly of the Presbyterian Church of Australia: September 1936, PCA: 63-64; also Duguid 1972: 120-121.

58 Hains 2003: 33. 
During this period, Duguid retained Love's full support. ${ }^{59}$ The Kunmunya missionary was forthright on the Smith funds and the AIM: he was 'disappointed' that John Flynn was hostile to the Mission. He understood, he said, the chief reason: 'dislike of losing the "Smith of Dunesk" money'. Love was also critical of the modus operandi of the AIM regarding Aborigines, suggesting that the AIM tended 'to follow the lead of the station people in this [hostile] attitude to the blacks, rather than give the lead.' Love called for 'justice for the blacks' ${ }^{60} \mathrm{He}$ also offered to help in the establishment of Ernabella, making two visits to the mission site in 1937 in preparation for the mission. Love's Report to the Board recommended that the mission proceed as planned. The publicly circulated versions of this Report excised a section that had trenchantly criticised the attitude of the AIM towards Aborigines. ${ }^{61}$ Perhaps not surprisingly, the Board of Missions had decided that it was neither politic nor sensible to fan the flames of division within the Church, or to upset the powerful figure of Flynn.

Love attempted unsuccessfully to persuade the 1938 Assembly of the South Australian Church to divide the annual Smith of Dunesk funds equally between the AIM and Ernabella Mission. The Church did, however, grudgingly and gradually, allocate more to Duguid's venture than it had the previous year, ${ }^{62}$ and concern grew within the AIM as to the ultimate trajectory of the distribution. ${ }^{63}$ In 1939 the Church in Scotland, as trustees of the gift, suddenly sold the Smith of Dunesk properties on the grounds that Mrs Smith's original intentions regarding the 'education and evangelisation' of the Aborigines of South Australia had to be given weight now that, with the establishment of Ernabella, there was 'an activity among them' (the Aborigines). ${ }^{64}$ The Scottish Church directed that the

59 Pastor Albrecht also continued to offer Duguid positive support for his mission. He told the Adelaide doctor that he, too, had had his differences with Church colleagues who thought it was a foolish thing to do to waste time and money on Aboriginals': Albrecht to Duguid (copy), 29 November 1935, Burns-Albrecht Collection, South Australian Museum Archives, AA662.

60 Love to Duguid, nd, probably late November 1936, Duguid Papers, NLA, MS 5068, Series 1.

61 The unexpurgated version was originally appended to a letter written by Love to the Board of Missions: Love to Matthews, 16 July 1937, Papers of JRB Love, MC, SLSA, PRG 214, Series 1, general correspondence: item 82. The edited version of the Report was published in the Minutes of Proceedings of the 1939 General Assembly of Australia. A characteristic example of Love's (excised) criticism of the AIM: 'I am shocked and distressed at the attitude of the Presbyterian Church towards the Aborigines, as evidenced by the AIM hostel at Oodnadatta. No one with long experience of life in the bush would advocate that Aborigines and whites should be cared for in the same ward; but the care of the Aborigines at this hostel is far from satisfactory.'

62 Presbyterian Church of SA, Blue Books, 1937, Report of Smith of Dunesk Committee, Financial Statement, PCSA Papers, MC, SASL; also see Minutes 9 and 37.

63 Presbyterian Church of SA, Minutes of AIM Executive 19 April 1938 (Minute 38/152), PCSA Papers, MC, SASL, SRG 123/360.

64 Webster to Martin, 4 September 1939, Presbyterian Church, PCSA Papers, MC, SASL, SRG123/331. It is hard to avoid the conclusion, however, that the 'home' church had finally lost patience with squabbling colonials in the 'paradise of dissent' and washed its hands of the matter. Future negotiations regarding the dispersal of the funds, now capitalised, were left entirely in the jurisdiction of the South Australian Church. 
interest from the proceeds of the sale be divided equally between the AIM and Ernabella. ${ }^{65}$ The pro-AIM forces in South Australia fought a rearguard action to retain their preponderant share of the income but the game was up.

The intervention of the overseas Church had finally tipped the balance in the Smith of Dunesk matter firmly in the direction of the pro-Ernabella forces. The 1940 Assembly voted to provide half of the available Smith of Dunesk funds to Ernabella. Duguid had wanted three-quarters. His frustration at this outcome was countered by his optimism over the announcement of the appointment of JRB Love as Superintendent of Ernabella, to take effect from March 1941. Duguid thought this appointment 'the greatest stroke of fortune for Ernabella' ${ }^{66}$ With its hand finally forced, the South Australian Assembly in 1942 determined that three-quarters of the Smith Funds were to be allocated to Ernabella, and one-quarter to the AIM. It was to remain at this allocation into the future. ${ }^{67} \mathrm{It}$ was a full seven years since Duguid had forced the issue and a century since the donor had made clear her intention to assist the Aborigines of South Australia, 'with not a farthing to the whites'. The AIM had been wounded slightly in the skirmish over the Scottish monies but in the larger scheme of things it moved on irresistibly, simultaneously creating and attaching itself to powerful national narratives of development, progress and nation-building.

\section{Re-evaluating Flynn}

At the end of this small but significant episode in parochial Presbyterianism, what do we now make of the myth of 'John Flynn', national saint? Successive commentators have had increasingly to consider Flynn's relationship with Indigenous Australians. In Ion Idriess's hagiography in 1932, which spectacularly constructed the icon of Flynn of the Inland, Aborigines are almost completely absent except as exotic, dangerous savages, speaking (but not heard) in 'guttural' tones, and spearing cattle and white men in 'bad-nigger' country. ${ }^{68}$ The first 'official' biography in 1963, by Scott McPheat, treats the Flynn narrative as solely having reference to white people. ${ }^{69}$ 'Aborigines' are not mentioned in the index, and rarely in the text. Little is revealed in McPheat's book of Flynn's attitudes to the Aborigines, unless one can infer something from the silence. A recent biography on Flynn by Max Griffiths, in 1993, provides

\footnotetext{
65 The proceeds from the sale of the properties were \5792, a not inconsiderable sum at the time.

66 Duguid to Webster (copy), 30 September 1940, Duguid Papers, NLA, MS 5068, Series 1.

67 How far into the future is unclear, although Reverend Bill Edwards, the last missionary superintendent at Ernabella before it was given back, with the Pitjantjatjara Lands, to the Pitjantjatjara (Anangu) people in the early 1980s, thought it was possible that monies from the 'Smith Fund' were still being distributed to Ernabella in the late 1970s: Reverend Bill Edwards, pers comm, 2002.

68 Idriess 1932.

69 McPheat was a padre in the AIM and was commissioned by the organisation to write Flynn's biography nine years after his death in 1951.
} 
a more comprehensive and balanced assessment of Flynn's attitudes towards Aboriginal people. ${ }^{70}$ Although writing of Flynn from a position of sympathy and admiration, Griffiths acknowledges a racial element present in Flynn's thinking, but sees it as a reflection of the attitude of most of the Australian community. Flynn shared with that community the idea that Aborigines were a poor and primitive people who were likely to remain so, and were thus, in a sense by definition, excluded from the 'imagined community' of the Inland and the rest of the nation. Yet, somewhat incongruously, a smiling Aboriginal stockman adorns the frontispiece of Griffith's book.

Brigid Hains's 2002 book, The Ice and the Inland: Mawson, Flynn and the Myth of the Frontier, confronts Flynn's alleged racism even more directly. ${ }^{71}$ Hains argues the frontier has become embedded in the modern Australian imagination as a permanent fixture, a potent myth, as she says, of a nation tempered by the struggle to live in an extreme natural environment. She sees Flynn, along with Douglas Mawson, as central to the creation of the frontier myth. These two 'heroes', she concludes, were essentially nation-builders, shaping and enhancing the 'symbiotic relationship' between the metropolis and the frontier. ${ }^{72}$ Hains, like Griffiths, accepts Flynn's 'blind spot' in relation to the Aborigines and the racial problems of the frontier but places him somewhere in the middle of the spectrum of the racial attitudes of his day. In a subsequent article, examining Duguid's charges against Flynn, Hains has again provided a nuanced and sympathetic picture of a man who, while occasionally denouncing the treatment of Aboriginal people, was 'slow to do anything about it in his own institutions'. As Love suggested at the time, Hains concurs that Flynn and the AIM formed an alliance with a deeply racist white settler culture that left them on one side of a great divide. Nevertheless, she cautions against 'moralistic historical judgment' on Flynn's 'incomplete humanitarian vision' ${ }^{73}$ The whole matter is also complicated, Hains suggests, by Duguid's apparently complacent acceptance of the need for removal of mixed-blood Aboriginal children from missions in the name of uplift and improvement. ${ }^{74}$ It is true that most actors in Central Australia were enmeshed, to a greater or lesser extent, in the implicating discourses of the time. Very few came, or left, with clean hands. It is perhaps ironic that Flynn himself saw this clearly: Australians, he wrote once, who 'have been reading to Aborigines the "move aside" clause, will surely be called up to render an account of our stewardship - God only know how soon'. ${ }^{75}$ 
I have argued that by apparently aiding and abetting attempts to resist Duguid's efforts to attach resources clearly misappropriated to European uses to an Aboriginal cause and to establish a Mission for Aborigines John Flynn was pursuing policies directly inimical to Indigenous welfare and interests. It is highly unlikely that Flynn did not know the details behind the Smith of Dunesk controversy or believed that since the Deed of Gift did not specify Aboriginals as recipients that that was the end of the argument. Duguid raised all these matters in his Moderator's Address, and afterwards in a number of public statements, as well as private correspondence to authorities within the Presbyterian Church, in which he pointedly referred to the AIM's (mis)appropriation of the money. At the very least, as JRB Love said, it would have been a 'fine thing' for the AIM to have released the money willingly. As well, Howard Zelling, an eminent jurist, noted during the Flynn 'furore' in 1972 that John Flynn was Moderator-General of the national Presbyterian Church of Australia during the Smith of Dunesk controversy and that 'he certainly did not use the weight of his high office to help Dr. Duguid's struggle to get justice for Aborigines'.$^{76}$ The early history of the Smith Fund may have been clouded by misinformation, but from 1935 at least, when Duguid shone a coruscating light on the matter of 'taking of blacks' money to help the whites', as Love had put it, it was incumbent on Flynn to react. That he reacted the way he did suggests a strategy of subtle resistance to Ernabella, possibly confirmed by his behaviour at the 1936 General Assembly.

Love's arguments against his Flynn on behalf of the Aborigines, had two underlying premises. The first was the simple but profound point that their need was greater than that of the whites. The second was that if Flynn, as a respected voice in the Centre, had made more positive interventions in favour of Aborigines, he might have shifted white settler opinion to a more sympathetic stance. Yet Love also understood, from his experience of the bush, the power of the resistance to that shift, that indeed respect was granted to the AIM by white settlers precisely because Flynn, while a 'religious man', was seen as 'one of us', a white man, advocating white colonisation of the Inland, with an implied exclusion of the blacks. ${ }^{77}$ Love appears to have accepted that this was an understandable, if regrettable, constraint on Flynn's freedom of action. However, these matters continue to leave a stain on his reputation as a 'national saint'. Indeed, it was the 'straight-out' Albrecht, on whose mission Flynn had first tested Traeger's famous wireless sets, who once said of the AIM founder

\footnotetext{
76 The Advertiser (South Australia), 6 September 1972: 5.

77 That this is not the whole story is evident in that missionaries, such as Winifred Hilliard and FW Albrecht, people sympathetic to Aborigines, and who devoted their lives in service with them, continued to respect Flynn, despite recognising some lack of fervour on his part regarding Aborigines.
} 
that 'it is wrong to surround Flynn with a sort of a halo of a saint' and that acts of discrimination by the AIM against Aboriginal people 'cast a dark shadow over Flynn and his work' ${ }^{78}$

\section{Conclusion}

John Flynn saw the Inland as a vast palimpsest over the inexorable erasure of whose original, Indigenous inscriptions he wished to write the nation-building, domesticated, racially homogenous script of modernity. ${ }^{79}$ Duguid and Love were also inexorable in their opposition to this erasure, although Love may have accepted its inevitability. While Flynn and Duguid, ironically, shared similar beliefs, in a Protestant Gospel of Social Justice, with a humanitarian rather than an evangelical vision and the necessity for the development of the Inland as a necessary ingredient in nation building, they parted ways on the matter of the Aborigines. We can hardly accuse Duguid of indifference to the fate of the Aboriginal people of the continent. One senses with Flynn something akin to the process which occurred with Arthur Phillip at the beginning of the European encounter with the Aborigines of this continent, memorably described by WEH Stanner in the first issue of Aboriginal History as 'the history of indifference thus begins'. ${ }^{80}$ In fact, at some point, Flynn's indifference appears to have developed into a sort of stubborn intractability on the matter of the Aborigines, whether through frustration, money concerns for the AIM, empathy for settler sentiment, personality clashes, or ideology, or perhaps a hardening amalgam of all these factors. JRB Love, on the other hand, had steered a middle course between these two restless engines of energy and ambition, Flynn and Duguid. In the end, Love's sense of his 'bad conscience', of the inexorability of the duty owed to the 'blacks', an obligation born out of the original dispossession, held sway for him, as it had not for John Flynn. Love, although often caught in racialist discourses, diverged, when it mattered and to his credit, towards the cause of the peoples whose mythic worlds Flynn's inexorable white men had usurped.

78 Letter from Pastor FW Albrecht re Dr John Flynn, nd, Albrecht Material 1926-1978, Lutheran Archives. The 'straight-out' reference is to the title of Albrecht's biography: Henson 1994.

79 I wish to use the concepts from the title of one of Emmanuel Levinas' essays, 'Bad Conscience and the Inexorable', as a sort of unifying theme for this conclusion: see Levinas 1986. It seems to me that the notion of a 'bad conscience', or more precisely the sensitivity or lack of sensitivity to a 'bad conscience' summarises the distinction I am trying to draw here between Love and Duguid on the one hand and Flynn on the other. The inexorability of the careers and personalities of Flynn and Duguid especially, on many layers, requires little comment. Duguid died in his 103rd year, still apparently fuming at Flynn until the end.

80 Stanner 1977. 


\section{References}

\section{Primary sources}

Papers of FW Albrecht, Burns-Albrecht Collection, AA662, South Australian Museum Archives, Adelaide.

Albrecht, FW, Albrecht Material 1926-1978, Lutheran Archives, Adelaide.

Papers of Charles Duguid, MS 5068, Series 1: general correspondence: 19181974, National Library of Australia (NLA), Canberra.

Duguid, Charles 1946, The Aborigines of Australia: Broadcasts and an Address, Australian Broadcast Corporation, Adelaide.

Papers of John Flynn, MS 3288, NLA, Canberra.

Flynn, John 1910, The Bushman's Companion: A Handful of Hints for Outbackers, Brown, Prior \& Co, Melbourne.

— 1913, 1915, issues of the Inlander, 1(1) 1913; 2(1) 1915.

Papers of JRB Love, Mortlock Collection, PRG 214, State Library of South Australia, Adelaide.

Love, JRB 1915, The Aborigines: Their Present Condition as seen in Northern South Australia, the Northern Territory, North-West Australia and Western Queensland, Arbuckle, Waddell and Fawckner, Melbourne.

— 1922, Our Australian Blacks, Brown, Prior Co Pty Ltd, Melbourne.

- 1936, Stone-Age Bushmen of Today: Life and Adventure among a Tribe of Savages in North-Western Australia, Blackie and Son Ltd, London and Glasgow.

Papers of the Presbyterian Church of Australia, ML MSS 1893, Mitchell Library, Sydney.

— 1936 Minutes of Proceedings of the 1936 General Assembly of the Presbyterian Church of Australia, Sydney.

Papers of the Presbyterian Church of South Australia, Mortlock Collection, State Library of South Australia, Adelaide.

Presbyterian Church of South Australia, 'Minutes of Proceedings of the South Australian State Assembly of the Presbyterian Church of Australia (Blue Books)', Mortlock Library, Adelaide. 
Passionate Histories

\section{Secondary sources}

Anderson, Warwick 2002, The Cultivation of Whiteness: Science, Health and Racial Destiny in Australia, Melbourne University Press, Melbourne.

Behr, John 1990, 'Traeger, Alfred Hermann (1895-1980)', Australian Dictionary of Biography, vol 12, Melbourne University Press, Melbourne: 251-252.

Biskup, Peter 1973, Not Slaves not Citizens: The Aboriginal Problem in Western Australia, 1898-1954, University of Queensland Press, St Lucia.

Broome, Richard 1994, Aboriginal Australians: Black Responses to White Dominance 1788-1994, 2nd edn, Allen \& Unwin, St Leonards, New South Wales.

Duguid, Charles 1972, Doctor and the Aborigines, Rigby, Adelaide.

— 1978, 'Tribal Nomadic People', Australasian Nurses Journal 7(12): 27.

Fischer, Tim 2009, 'An overdue salute: John Monash of Jerilderie and Melbourne', Sydney Papers 20(4): 134-141.

Godfrey, John R and John Ramsland 2004, 'David, Stanley and Norman Drummond: a "fair deal" for the New South Wales country child in schooling and welfare, 1924-1983', in Journal of the Royal Australian Historical Society 90(1), June: 22-35.

Griffiths, Max 1993, The Silent Heart: Flynn of the Inland, Kangaroo Press, Kenthurst, New South Wales.

Hains, Brigid 2002, The Ice and the Inland: Mawson, Flynn, and the Myth of the Frontier, Melbourne University Press, Melbourne.

— 2003, 'Inland Flynn: Pioneer? Racist? Or Product of His Time?', Eureka Street, May: 31-34.

— 2004, 'Antipodean Alchemist', Meanjin 63(1): 27-33.

Harris, John 1990, One Blood: 200 Years of Aboriginal Encounter with Christianity: A Story of Hope, Albatross, Sydney.

Henson, Barbara 1994, A Straight-out Man: FW Albrecht and Central Australian Aborigines, Melbourne University Press, Melbourne.

Hilliard, Winifred 1976, The People in Between, Seal Books, Rigby, Adelaide.

Idriess, Ion 1973[1932], Flynn of the Inland, Angus \& Robertson, Sydney, [A\&R Classics]. 
Levinas, Emmanuel 1986, 'Bad conscience and the inexorable', in Face to Face with Levinas, Richard A Cohen (ed), State University of New York Press, Albany: 35-40.

McKenzie, Maisie 1969, The Road to Mowanjum, Angus and Robertson, Sydney.

McPheat, W Scott 1963, John Flynn: Apostle to the Inland, Hodder and Stoughton, London.

Nelson, Penelope 2001, 'National vision, John Flynn and the blind spots of leadership', Sydney Papers 13(2): 20-32.

Rowse, Tim 1998, White Flour, White Power: From Rations to Citizenship in Central Australia, Cambridge University Press, Melbourne.

Rudolph, Ivan 2000, John Flynn: of Flying Doctors and Frontier Faith, 2nd edn, Central Queensland University Press, Rockhampton, Queensland.

Scrimgeour, Robert J 1986, Some Scots Were Here: A History of the Presbyterian Church in South Australia 1839-1977, Lutheran Publishing House, Adelaide.

Stanner, WEH 1977, 'The history of indifference thus begins', Aboriginal History 1(1): 3-26.

Trudinger, David 2004, 'Converting Salvation: Protestant Missionaries in Central Australia, 1930s-1940s', unpublished PhD thesis, Australian National University, Canberra. 